Acta Crystallographica Section D

Biological

Crystallography

ISSN 0907-4449

\section{David Mervyn Blow: a scholar and a gentleman (1931-2004)}

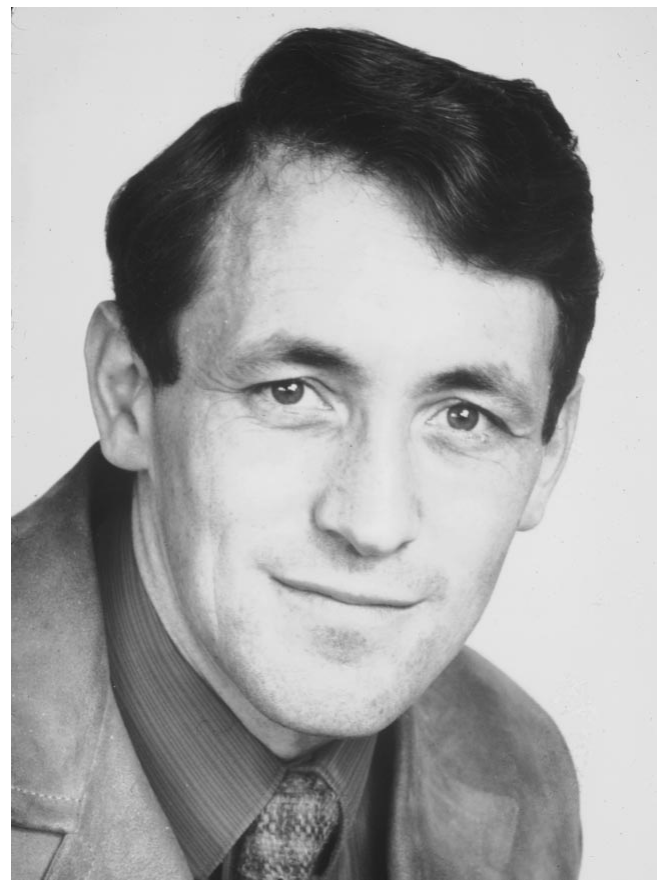

My association with David Blow (photograph ca 1967), which was a pivotal step in my career, was due more to good luck than good management. As a $\mathrm{PhD}$ student in Australia working in 'small molecule' crystallography, I had written to Max Perutz asking about the possibility of doing postdoctoral work in his laboratory and was very excited to be accepted.

My wife and I arrived in Cambridge in November 1963, the same week that President Kennedy had been assassinated. The Union Jack over the Medical Research Council laboratory was flying at half-mast, an extraordinarily rare sign of respect under any circumstances, let alone for a non-citizen.

When I introduced myself to Perutz he indicated that, since we had first corresponded, two other postdoctoral associates had already joined his group. If I still wanted to work with him I would be free to do so, he said, but at the same time he strongly urged me to consider the possibility of joining another group within the MRC laboratory.

David Blow's group was one such possibility. I was aware that David had several publications in protein crystallography but the only article of his that I had read with any care was the note 'To fit a plane to a set of points by least squares'. It is possibly his least-quoted publication but one which was relevant to my thesis project. I was, however, immediately taken with David's personality and sensed that we would get on well together. Furthermore, Michael Rossmann, who had been David's long-standing collaborator, was about to assume a new position at Purdue University. Also his technician, Barbara Jeffery, was about to move to the Boston area. I had little hesitation in joining David's group. Paul Sigler was to join six months later, technically as a $\mathrm{PhD}$ student although with substantial prior experience in David Davies' laboratory and as a practising MD 
Richard Henderson joined the group as a starting graduate student in 1966. By early 1967 David's team had determined the structure of $\alpha$-chymotrypsin. There was no question I had made the right decision.

David Blow died on 8 June 2004, aged 72. Although a lifetime non-smoker, in 2003 he was diagnosed with lung cancer which was already far advanced and inoperable. Those who visited him during the subsequent months found him to be remarkably up-beat. Among other things he even found time to write a short novel.

David was born the second son of a Methodist minister who had worked as a missionary in Madras, India. In 1948 he won an open scholarship to Corpus Christi. This did not free him from a military service obligation during which he joined the Air Force and learned to fly gliders.

As an undergraduate he was interested in doing research in radio astronomy but on graduation found that support would be more readily available in biophysics. Specifically, Max Perutz had funds for students to work on crystallographic studies of proteins. Perutz, at that time, had something of a mixed reputation. As David Davies, who was a student at Oxford, has told me, the general opinion among many small-molecule crystallographers at the time was that 'if only Max Perutz were a bit smarter he would realize what a waste of time it is to try to determine the structure of a protein'. David consulted the Master of his college, Sir George Thompson, who had a very different opinion, 'physics is going to be very important in biology in the next half-century. You have a wonderful opportunity. Go for it!'. This was the advice that David wanted to hear and he immediately joined Perutz's group.

As all crystallographers will know, David's PhD project was to find a way to generalize the use of isomorphous replacement to determine the phase angles of the 'non-centrosymmetric' reflections. This led to his famous paper with Francis Crick. David said, in retrospect, that he thought that the extensive calculations required for each individual reflection would greatly restrict the use of the BlowCrick algorithm and, as such, it would be something of an intellectual curiosity. He did not anticipate that the dramatic increase in power and availability of computers in the following few years would not only make it the workhorse of day-to-day phase determination in proteins but also that his analysis would be the stepping-off point for all future approaches based on isomorphous replacement and anomalous scattering.

Toward the end of a two-year postdoctoral stint with Alex Rich in the US, and no doubt influenced by his missionary roots, David considered teaching in what is now Zimbabwe. He was, however, delighted to be invited to return to the MRC laboratory as a staff member. This led to a highly productive collaboration with Michael Rossmann in which they developed the foundations of the molecular replacement method. The early structural studies of hemoglobin and myoglobin by Perutz and Kendrew had shown that hemoglobin is made up of four structurally similar domains and that each of these is similar to myoglobin. Rossmann and Blow felt that these structural correspondences ought to be determinable from the crystallographic data. Michael brought brilliance and unbounded enthusiasm. David also brought brilliance coupled with a certain down-to-earth practicality.

During this period David also began to work on structural studies of $\alpha$-chymotrypsin. Using the new methods that they had developed Blow and Rossmann determined the location of a presumed twofold axis of symmetry that related the two molecules in the asymmetric unit. This was confirmed by the subsequent structure determination. 
David was an extraordinarily generous colleague and mentor. During the period that we were working on the $\alpha$-chymotrypsin project, all of the computer programs were written in-house. David suggested that I should write a phasedetermination program based on the Blow-Crick algorithm. This was something that he could have done in his sleep but he felt that it would be a useful learning exercise for me. Work on this program led immediately to ideas about the combination of isomorphous replacement and anomalous scattering data. When this was written up, however, David insisted that he not be included as a coauthor even though the work would not have been done without his input. Similar stories are heard over and over from his former students and colleagues.

As well as his scientific generosity toward his immediate coworkers, David also felt a strong sense of obligation toward the broader community. Having moved in 1977 to establish a biophysics group at the Imperial College of Science and Technology in London, David was shortly asked to serve as Dean (1981-1984). Later (1991-1994) he served as Head of the Department of Physics. He was instrumental in forming the British Crystallographic Association and from 19861988 served as its President.

Following the development of a serious heart condition, David took early retirement in 1994 and took up permanent residence with his wife, Mavis, in the small seaside town of Appledore in Devon. Mavis was an enthusiastic participant in the local brass band and David would help raise funds for new instruments by 'passing the hat' during local performances. David also served as Chairman of the local branch of the Campaign to Protect Rural England, giving careful attention to the preservation of the unspoiled vistas near Appledore.

During his career David made contributions to the two methods that dominate macromolecular structure determination. The Blow-Crick formalism was central to the development of the isomorphous replacement method and the related use of anomalous dispersion data. Also, his contributions with Michael Rossmann laid the foundations for the now ubiquitous molecular replacement method. As well, he was responsible for one of the first determinations of a protein structure.

These and other contributions were recognized by his early election to the Royal Society (1972). Among other awards, he shared with David Phillips the Charles Leopold Meyer Prize in 1979 and the Wolf Foundation Prize for Chemistry in 1987.

To his immediate colleagues David was an invaluable friend and mentor. His scientific generosity was extraordinary yet, at the same time, he also had an underlying sense of competitiveness and was concerned that credit should be given where credit is due. To the community at large he was a person of common sense and good judgement whose advice was always freely and generously given. He truly was a scholar and a gentleman.

He is survived by his wife, Mavis, and a son and daughter.

\section{Brian W. Matthews}

Institute of Molecular Biology and Howard Hughes Medical Institute University of Oregon

Eugene

OR 97403-1229

USA

E-mail: brian@uoxray.uoregon.edu 